\title{
When science meets religion in the classroom
}

SIR - In the Editorial "Dealing with design" (Nature 434, 1053; 2005), Nature claims that scientists have not dealt effectively with the threat to evolutionary biology posed by 'intelligent design' (ID) creationism. Rather than ignoring, dismissing or attacking ID, scientists should, the editors suggest, learn how religious people can come to terms with science, and teach these methods of accommodation in the classroom. The goal of science education should thus be "to point to options other than ID for reconciling science and belief". In this way, students' faith will not be challenged by scientific truth, and evolution will triumph.

This suggestion is misguided: the science classroom is the wrong place to teach students how to reconcile science and religion. For one thing, many scientists deem such a reconciliation impossible because faith and science are two mutually exclusive ways of looking at the world. For such scientists, Nature apparently prescribes hypocrisy. The real business of science teachers is to teach science, not to help students shore up worldviews that crumble when they learn science. And ID creationism is not science, despite the editors' suggestion that ID "tries to use scientific methods to find evidence of God in

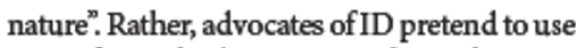
scientific methods to support their religious preconceptions. It has no more place in the biology dassroom than geocentrism has in the astronomy curriculum.

Scientists are of course free (some would say duty-bound) to fight ID outside the classroom, or to harmonize religion with science. But students who cannot handle scientific challenges to their faith should seek guidance from a theologian, not a scientist. Scientists should never have to apologize for teaching science.

\section{Jerry Coyne}

Department of Ecology and Evolution, University of Chicago, Chicago, Illinois 60637, USA

Peter Atkins Lincaln Colege, University of Oxford

Colin Blakemore Medical Reseorch Counoll, London

RichardDawkins Oxford Uhiversity Mus am, Uhiversity of Onford

Steve Jones Galton Labovatories, University College Landon

Richard Lewontin Mu soum of Comporotive Zoolog;, Honerd Uhiversity

John Madd ax 9 Pitt Street, London W8 $4 \mathrm{NX}$

PaulNurse The Rock d oller Uniersit, New Yoit

Linda Partridge Deportment of Biabgy, University College London James D. Watson Cold Sawing Harbor Laboratoriks, New Yart

Steven Weinberg Deportment of Physica, Univers ky of teros, Austh Lewis Wolpert Department of Anatomy and Devolopmental Bialogx. University College London

\section{Teaching about ID helps students see its flaws}

SIR - I have regularly taught seminars for university biology majors, which compare the scientific claims of evolution and ID. In doing so, I am not advocating the scientific merits of ID, as discussed in your News Feature "Who has designs on your students' minds?" (Nature 434, 1062-1065; 2005). I view these seminars as analogous to media literacy courses. To understand why $80 \%$ of Fox News viewers had misperceptions about Iraq, such as believing that weapons of mass destruction had been discovered there (see www.pipa.org), media students need to learn how Fox News operates. Such a media literacy course does not necessarily vouch for the veracity of any particular Fox show.

My interest in ID was sparked in 1999 by a local high-school teacher who used ID materials in a biology course. Parents and citizens successfully defended the teaching of mainstream science against proponents of ID, in this case the Discovery Institute (see www.scienceormyth.org). This taught me how effective pro-evolution groups are when they work with the school administration, and are supported by faculty from local colleges and universities. But to be effective in its support, the scientific community needs to understand the empirical claims of ID.

Although it seems to have been resurrected for religious or cultural agendas, ID's proponents have made empirical claims that can be examined. Many college students are curious about ID but have little knowledge of the daims made for it. In my experience, upper-level biology students with the appropriate background in molecular biology, genetics, developmental biology and evolution are capable of distinguishing the scientific merits of evolutionist and ID claims - to the great disadvantage of ID.

Students who themselves determine that ID does not cut the scientific mustard will be more effective in their support of teaching mainstream science. Students who remain creationists or fence-sitters will at least have a better understanding of why ID has not been widely accepted in the scientific community.

It may seem contradictory to offer a course on ID and evolution in colleges and oppose teaching ID in high schools. But high-school students are just learning the basics of science. To expect them to make a well-reasoned judgement about the status of any scientific theory, including evolution, is unrealistic. David Leaf

Department of Biology, Western Washington University, Bellingham, Washington 98225, USA

\section{Evolution is a short-order cook, not a watchmaker}

SIR - The visual shock of last week's 'intelligent design' cover was matched by the perceptiveness of your News Feature (Nature $434,1062-1065 ; 2005$ ) on the seepage of this slyly religious ideology into science curricula. This stuff should certainly be kept out of high schools, but I am ambivalent about its presence in our universities, where free discussion is of greater value than correctness - political, scientific or otherwise.

On the other hand, I'd be properly rebuked and sanctioned for incompetence if I were to assert in my undergraduate physicalchemistry course that the intricate, precisely exponential distribution of velocities observed in a collection of gas molecules is simply too perfect and beautiful to have arisen from random collisions, but that we should instead consider a mechanism by which intelligent designers - let's call them

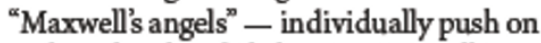
each molecule, while keeping in intelligent communication with each other to maintain this distribution.

One reason that scientists famously fail in rebutting ID is that we use the wrong analogies. Evolution is not a blind watchmaker or any other kind of engineer, but rather a short-order cook, and - looking at the phenomenally complicated structures one who is less like Isaac Newton than Rube Goldberg or W. Heath Robinson.

A terrific argument against ID came to me recently after two consecutive talks, one on the Wnt signalling pathway, the next on G-protein crosstalk in control of cellular calcium. Just look at the details, and you'll immediately abandon all thoughts that biological systems were designed with any intelligence whatsoever.

Chris Miller

HHMI, Department of Biochemistry, Brandeis University, Waltham, Massachusetts 02454, USA

\section{Seeking evidence of God's work undermines faith}

SIR - Your Editorial about the promotion of ID in schools and universities (Nature 434, $1053 ; 2005$ ) asks us to persuade our students that science and faith do not compete, but for Christians this should always have been clear. In the Bible (John 20: 25-29), Thomas doubts that the man speaking to him is the resurrected Christ until Jesus reveals his wounds. Thomas then believes, but Jesus says: "Blessed are those who have not seen and yet have believed".

The Bible throughout teaches that faith is 